\title{
ENDOSCOPIA RINOSINUSALĂ, O METODĂ MODERNĂ DE DIAGNOSTIC ŞI TRATAMENT
}

\section{Dr. Bidilean Nicolae - medic primar O.R.L., doctor în ştiințe medicale}

Stud. Bidilean Maria-Cristina

Stud. Bidilean Sânziana-Alexandra

\section{Introducere}

Endoscopia rinosinusală reprezintă o metodă de diagnostic şi tratament care s-a dezvoltat foarte mult în ultimele 2 decenii. În țara noastră această metodă a pătruns la începutul anilor 90, când o serie de specialişti români au avut ocazia să efectueze cursuri de pregatire în străinătate, ulterior fiind achiziționată aparatura necesară.

\section{Scopul lucrarii}

Evidențierea avantajelor aplicării acestei metode în diagnosticul afecțiunilor rinosinusale, precum şi aportul diagnostic în coroborare cu alte metode de diagnostic (radiologice, CT, examen bacteriologic, examen citologic, examen histopatologic).

\section{Material şi metodă}

În lucrarea de față, am luat în considerare examinările şi intervențiile efectuate endoscopic în secția ORL a Spitalului Județean Satu Mare în perioada 1995-2006. Instrumentarul şi aparatura utilizată este o combinaţie între trusa MLM şi STORZ, sursa de lumină, opticile de 30 şi 80 de grade, pense diferite. Pentru înregistrarea imaginilor am utilizat videocamera STORZ. Pacientilor li s-a efectuat endoscopia nazală, endoscopia sinusală maxilara pe calea fosei canine sau a meatului inferior, iar în funcție de patologie s-a procedat la biopsierea formațiunilor nazale şi sinusale, ablația de formațiuni nazale, polipi, corecția variațiilor de structură ale peretelui nazal lateral. Prin lumenul trocarului de puncție s-a efectuat aspirația secrețiilor sinusale, biopsia mucoasei, extragere de corpi străini, plasarea unui tub de dren în meatul inferios în scop de drenaj. Examinarea endoscopică a fosei nazale s-a efectuat pe calea celor 3 culoare principale reprezentate de meatele nazale. Optica flexibilă (Olympus 20D) a fost folosită pentru studiul endoscopic al foselor nazale, a rinofaringelui, hipofaringelui şi laringelui.

\section{Condiderații anatomice şi fiziopatologice}

Peretele nazal lateral, prin reperele anatomice care îl formează, prezintă importanță practică. El este dominat de prezența celor trei cornete nazale: inferior, mijlociu şi superior, care delimitează trei meaturi. Cornetul inferior se articulează anterior cu osul maxilar, iar posterior cu osul palatin. El traversează hiatusul semilunar. Cornetul mijlociu, situat deasupra celui inferior, prezintă ca şi particularitate proeminarea capului, iar în unele situații, prin dezvoltarea excesivă a unor celule etmoidale, devine bulos (conca bulosa). Această tumefiere excesivă duce la îngustarea spațiilor de la nivelul complexului ostiomeatal. Anterior acesta se articulează cu ramura ascendentă a osului maxilar, iar posterior cu creasta turbinară a osului palatin. Coada cornetului mijlociu reprezintă reperul important în descoperirea găurii sfenopalatine. Cornetul superior se întinde de la treimea medie a cornetului mijlociu şi depăşeşte 
posterior coada cornetului mijlociu. Meatul inferior prezintă oficiul de deschidere al canalului lacrimal la aproximativ $1 \mathrm{~cm}$ de capul cornetului inferior, zona mijlocie este caracterizată prin subțierea peretelui osos. Aici este locul de elecție pentru efectuarea puncțiilor sinusale, a sinusoscopiei şi a meatotomiilor inferioare. Posterior, osul prezintă o rezistență sporită, fiind reprezentat de osul palatin.

Meatul mijlociu prezintă o serie de caracteristici anatomice cu importanță în patologia rinosinusală. La acest nivel se descriu: procesul uncinat- o lamă osoasă cu traiect oblic de sus în jos şi dinainte înapoi, şanțul uncibular, delimitat înainte de procesul uncinat, iar posterior de bula etmoidală; bula etmoidală, situata în spatele şanțului uncibular, ca o tumefiere a celulelor etmoidale; şanțul retrobular mărginit anterior de bula etmoidală, iar posterior de inserția cornetului mijlociu. Şanțul uncibular prezintă orificiile de deschidere ale canalului nazofrontal, celulele etmoidale anterioare şi ostiumul sinusului maxilar.

Prezența celor trei elemente osoase: procesul uncinat, bula etmoidală şi capul cornetului mijlociu permit descrierea a trei şanţuri: -şantul unciturbinal situat între procesul uncinat şi cornetul mijlociu; şanțul uncibular, situat între bula etmoidală şi procesul uncinat; şanţul intern sau buloturbinal, delimitat de cornetul mijlociu şi bula etmoidală. Şanțul medial şi lateral se unesc şi formează canalul colector al sinusurilor anterioare care se termină între coada cornetului inferior şi mijlociu.

La nivelul meatului superior se deschid celulele etmoidale posterioare, posterior se găseşte gaura sfenopalatină care cuprinde: artera sfenopalatină, ramuri venoase sfenopalatine şi ganglionul sfenopalatin.

Menținerea fiziologiei sinusurilor paranazale este asigurată de drenajul şi ventilația sinusală, alături de funcția de apărare a mucoasei şi funcția ostiumului sinusal. Drenajul sinusurilor paranazale reprezintă o funcție bazată pe mecanismul de secreție şi transport.
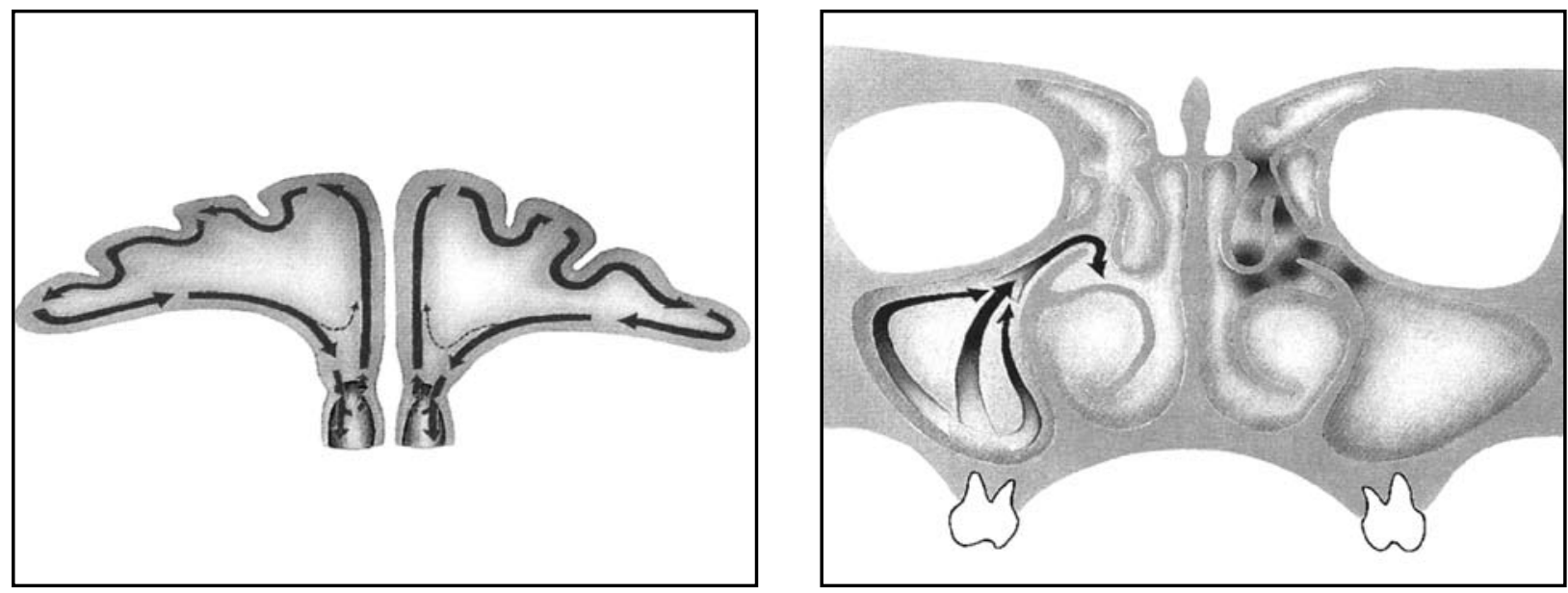

Stratul de mucus este produs de către glandele seromucoase şi celulele mucipare intraepiteliale. Mucusul este compus din 2 straturi: stratul intern, faza sol, apos, în care se mişcă cilii şi un strat extern numit faza gel, vâscos, care este transportat de mişcările ciliare. Clearance-ul mucociliar este asigurat la un pH de 7,5-7,6. Prin acest mecanism pulberile sunt încorporate în faza gel şi transportate în afara sinusurilor. De asemenea, fluxul aerian transnazal în cursul respirației după ce o inspirație forțată a creat o presiune negativă, favorizează transportul mucusului în afara sinusului.

În condițiile unei hipersecreții mucusul se acumulează în punctul decliv al sinusului. Dacă mucusul în exces este aspirat, transportul mucociliar se reia complet. $\mathrm{Cu}$ modificarea secreției de mucus, în sensul că devine mai vâscoasă, transportul mucociliar spre ostium devine mai lent, iar stratul de gel devine mai dens. La nivelul ostiumului se produce o acumulare de mucus, care ulterior se aşează pe planşeul sinusului.

Prin mecanismele de dizolvare el poate fi mai uşor transportat, în parcursuri repetate spre ostiumul sinusal. 
Endoscopia sinusala a permis observarea faptului că unele zone de mucoasă îşi transportă mucusul mai rapid decât zonele învecinate şi că acesta ajunge la ostium înaintea altor secreții (Messerklinger). S-a observat că după câteva minute zona mai lentă îşi poate accelera transportul, în timp ce zona rapidă încetineşte transportul secrețiilor.

\section{Rezultate şi discuții}

Patologia examinată prin metoda endoscopică a putut fi diagnosticată cu acuratețe sporită, ceea ce a permis aplicarea unui algoritm terapeutic.

Examinarea endoscopică a pacientilor cu rinită acută a permis vizualizarea stării mucoasei nazale, prezența secrețiilor, recoltarea acestora pentru examen bacteriologic, starea anatomică a complexului ostiomeatal.

În cazul rinitelor cronice hipertrofice şi atrofice, endoscopia nazosinusală a evidențiat starea mucoasei, culoarea, grosimea ei, variații de calibru ale foselor nazale. De asemenea, endoscopia a permis vizualizarea stării rinofaringelui, orificiului faringian al trompei lui Eustachio. Controlul endoscopic ne-a permis rezecția mucoasei cozilor de cornete în cazul rinitelor cronice hipertrofice care au determinat o insuficiență respiratorie nazală.

Alergia nazo-sinusală alături de polipoza nazosinusală a reprezentat un capitol important al aplicării endoscopiei nazosinusale. Studiul mucoasei şi recoltarea de secreții pentru examen citologic, bacteriologic, precum şi a biopsierii formaţiunilor suspecte ne-a permis confirmarea unui diagnostic de acuratețe şi luarea unei decizii terapeutice. Ablația formațiunilor polipoase nazosinusale a permis restabilirea drenajului şi ventilaţiei sinusurilor paranazale.

Pacientii cu sinuzite acute au beneficiat de examenul endoscopic şi efectuarea unei decongestii a mucoasei sinusale, identificarea variațiilor de structură a foselor nazale (deviația de sept, conca bulosa, cornet mijlociu cu curbura paradoxa), factori favorizanți în declanşarea procesului patologic. Prin recoltarea de secreții patologice şi însămânțarea lor pe medii de cultură, pentru identificarea germenului cauzator s-a reuşit aplicarea țintita a antibioterapiei.

Sinuzitele cronice prin patologia complexă care o prezintă, a reprezentat principalul domeniu de aplicare a examenului endoscopic. Prin identificarea variațiilor de structură a foselor nazale, precum şi alterările anatomice ale mucoasei complexului ostiomeatal, respectiv îngustarea spațiilor de la acest nivel, alterarea transportului mucociliar al secrețiilor, am reuşit un diagnostic de acuratețe care ne-a permis alaturi de examinarea CT şi RMN în unele situații, diferențierea de un proces tumoral concomitent. Sub control endoscopic s-a procedat la drenarea sinusului maxilar prin meatul inferior. Ablația porțiunilor de mucoasă alterată a contribuit la restabilirea drenajului şi a ventilației sinusale.

Leziunile precanceroase au beneficiat de explorarea endoscopică prin identificarea macroscopică a acestora, precum şi reluarea unei biopsii țintite, care a permis un diagnostic histopatologic de precizie.

Formațiunile tumorale ale foselor nazale au fost identificate endoscopic, biopsiate țintit, iar în coroborare cu examenul CT, RMN, ne-a permis evaluarea extinderii formațiunilor, afectarea situsurilor adiacente, limitele de extindere, stadializarea procesului, precum şi diferențierea de infecția fungică, care la nivel nazosinusal simulează o formațiune tumorala malignă. Toate leziunile suspecte de malignitate au fost biopsiate țintit, iar examenul histopatologic a fost suveran în precizarea diagnosticului.

\section{Concluzii}

Endoscopia rinosinusală, fiind o metoda microinvazivă, impune recunoaşterea reperelor anatomice rinosinusale, precum şi a datelor radiologice, CT, RMN, reducând la minim riscurile complicațiilor.

Intervențiile minim invazive permit recuperarea funcțională ulterioară în limite cvasinormale a mucoasei rinosinusale, evitând intervențiile largi cu consecințe neplăcute asupra stării de sănătate a pacientului. 
Coroborarea rezultatelor endoscopiei cu datele anamnezei şi a examenului CT permite diagnosticarea cu acuratețe a afecțiunilor rinosinusale.

Datorită acurateții diagnosticului oferite de endoscopia nazosinusală, se impune dotarea tuturor secțiilor de ORL cu aparatură şi instrumentarul necesar acestei metode.

\section{Bibliografie}

1. Albu, S.: Chirurgia endoscopică endonazală, Ed.Național 2000

2. Bidilean, N.: Rolul sinusoscopiei şi microendoscopiei în evaluarea modificărilor inflamatorii şi tumorale ale mucoasei rinosinuzale, Teza de doctorat UMF Tg. Mures, 1999

3. Messerklinger, W.: Die Rolle der lateralen Nasenwand in der Pathogenese, Diagnose und Terapie der rezidivierenden und chronischen Rhinosinusitis, Laryngorhinootologie, 66: 293-299, 1987

4. Stammberger, H.: Functional Endoscopic Sinus Surgery, B.C.Decker, Philadelphia, 1991. 